\title{
A review of current and emergent biofilm control strategies
}

\author{
Manuel Simões $^{\mathrm{a}, *}$, Lúcia C. Simões ${ }^{\mathrm{b}}$, Maria J. Vieira ${ }^{\mathrm{b}}$ \\ a LEPAE, Department of Chemical Engineering, Faculty of Engineering, University of Porto, Rua Dr. Roberto Frias, s/n, $4200-465$ Porto, Portugal \\ ${ }^{\mathrm{b}}$ IBB-Institute for Biotechnology and Bioengineering, Centre of Biological Engineering, University of Minho, Campus de Gualtar 4710-057 Braga, Portugal
}

\section{A R T I C L E I N F O}

\section{Article history:}

Received 15 July 2008

Received in revised form 23 September 2009

Accepted 15 December 2009

\section{Keywords:}

Biofilm control

Cleaning and disinfection

Dairy biofilms

Enzymes

Interspecies interactions

Microbial metabolites

Phages

\begin{abstract}
A B S T R A C T
Microbial adhesion to surfaces and the consequent biofilm formation has been documented in many different environments. Biofilms constitute a protected mode of growth that allows microorganisms to survival in hostile environments, being their physiology and behavior significantly different from their planktonic counterparts. In dairy industry, biofilms may be a source of recalcitrant contaminations, causing food spoilage and are possible sources of public health problems such as outbreaks of foodborne pathogens. Biofilms are difficult to eradicate due to their resistant phenotype. However, conventional cleaning and disinfection regimens may also contribute to inefficient biofilm control and to the dissemination of resistance. Consequently, new control strategies are constantly emerging with main incidence in the use of biosolutions (enzymes, phages, interspecies interactions and antimicrobial molecules from microbial origin).

The present review will focus on describing the mechanisms involved in biofilm formation and behavior, deleterious effects associated with their presence, and some of the current and emergent control strategies, providing new insight of concern for food industry.
\end{abstract}

(c) 2009 Elsevier Ltd. All rights reserved.

\section{Introduction}

More than 60 years after the first report on biofilms (Zobell, 1943), they are still a concern in a broad range of areas, and specifically in the food, environmental and biomedical fields (Flint, Bremer, \& Brooks, 1997; Maukonen et al., 2003; Sihorkar \& Vyas, 2001; Veran, 2002). It is a natural tendency of microorganisms to attach to wet surfaces, to multiply and to embed themselves in a slimy matrix composed of extracellular polymeric substances (EPS) that they produce, forming a biofilm. Biofilms are problematic in particular food industry sectors such as brewing, dairy processing, fresh produce, poultry processing and red meat processing (Chen, Rossman, \& Pawar, 2007; Frank, Ehlers, \& Wicker, 2003; Jessen \& Lammert, 2003; Somers \& Wong, 2004). Within the food industry, biofilm formation in dairy processing plants is a significant problem. Commonly when contamination of dairy products occurs the source of the problems is biofilm-related. There is good evidence indicating that the biofilm mode of life leads to increased resistance to antimicrobial products (Langsrud, Sidhu, Heir, \& Holck, 2003; Simões \& Vieira, 2009; Simões, Simões, Machado, Pereira, \& Vieira, 2006). Biofilms are more resistant to antimicrobials compared to planktonic cells and this makes their elimination

\footnotetext{
* Corresponding author. Tel.: +351 225081654

E-mail address: mvs@fe.up.pt (M. Simões).
}

from food processing facilities a big challenge (Simões \& Vieira, 2009; Simões et al., 2006). Moreover, the emergence of resistant bacteria to conventional antimicrobials clearly shows that new biofilm control strategies are required (Sidhu, Langsrud, \& Holck, 2001; Simões et al., 2006).

\section{Biofilms in the dairy industry}

The main sources of contamination of milk and related products are commonly due to improper cleaning and disinfection of equipment (Gibson, Taylor, Hall, \& Holah, 1999; Jessen \& Lammert, 2003). It is of utmost importance to sanitize the processing equipment taking into account both the inorganic composition of the deposits and also the constitutive microflora. Dairy biofilms are predominated by bacterial extracellular polymeric substances (EPS) and milk residues, mostly proteins and calcium phosphate (Flint et al., 1997; Mittelman, 1998). The formation of biofilms on dairy industry equipment can lead to serious hygiene problems and economic losses due to food spoilage and equipment impairment (Bremer, Fillery, \& McQuillan, 2006; Gram, Bagge-Ravn, Ng, Gymoese, \& Vogel, 2007). Microorganisms in biofilms catalyze chemical and biological reactions causing metal corrosion in pipelines and tanks, and they can reduce the heat transfer efficacy if biofilms become sufficiently thick at plate heat exchangers and pipelines (Mittelman, 1998; Vieira, Melo, \& Pinheiro, 1993). 
A significant number of reports have appeared on the persistence of some foodborne pathogens on food contact surfaces and biofilms, affecting the quality and safety of the food products. Outbreaks of pathogens associated with biofilms have been related to the presence of Listeria monocytogenes, Yersinia enterocolitica, Campylobacter jejuni, Salmonella spp. Staphylococcus spp. and Escherichia coli 0157:H7 (Aarnela, Lundén, Korkeala, \& Wirtanen, 2007; Dykes, Sampathkumar, \& Korber, 2003; Kumar \& Anand, 1998; Lapidot, Romling, \& Yaron, 2006; Sharma \& Anand, 2002a; Somers, Schoeni, \& Wong, 1994; Waak, Tham, \& Danielsson-Tham, 2002; Wong, 1998). Foodborne pathogens can enter the milk processing equipment by direct contact with contaminants in the dairy farm environment (e.g. faecal contamination and udders of infected animal) and also through the water used in the milking machines (Oliver, Jayarao, \& Almeida, 2005). These contaminating microorganisms can form biofilms that are difficult to eradicate and can act as a harbour and/or substrate for other microorganisms less prone to biofilm formation, increasing the probability of pathogen survival and further dissemination during food processing (Lapidot, Romling, et al., 2006; Lehner et al., 2005; Lomander, Schreuders, Russek-Cohen, \& Ali, 2004; Møretrø \& Langsrud, 2004). Postpasteurization contaminations of milk products are mainly due to the filling machines (Dogan \& Boor, 2003; Waak et al., 2002). Biofilms that can develop on the sides of gaskets may also be a source of post-pasteurization contamination (Austin \& Bergeron, 1995). Environmental surfaces such as floors and walls may also be indirect sources of contamination e.g. transference to the food products by vectors such as air, people and cleaning systems (Gibson et al., 1999; Holah, 1992).

In dairy environments, the most commonly encountered bacteria belong to the genus Enterobacter, Lactobacillus, Listeria, Micrococcus, Streptococcus, Bacillus (Fig. 1) and Pseudomonas (Salo, Ehavald, Raaska, Vokk, \& Wirtanen, 2006; Sharma \& Anand, 2002a; Waak et al., 2002; Wiedmann, Weilmeier, Dineen, Ralyea, \& Boor, 2000). Pseudomonas spp. are one of the most important bacteria causing spoilage of conventionally pasteurized liquid milk products, acting by two different routes. First, they produce the majority of lipolytic and proteolytic enzymes secreted into raw milk during pre-processing storage, even in psychrotropic environments. Many of these enzymes can survive pasteurization and even ultra-hightemperature treatments and can thus reduce the sensory quality and shelf life of the processed liquid milk products. Second, Pseudomonas spp. can act in the post-pasteurization process, causing

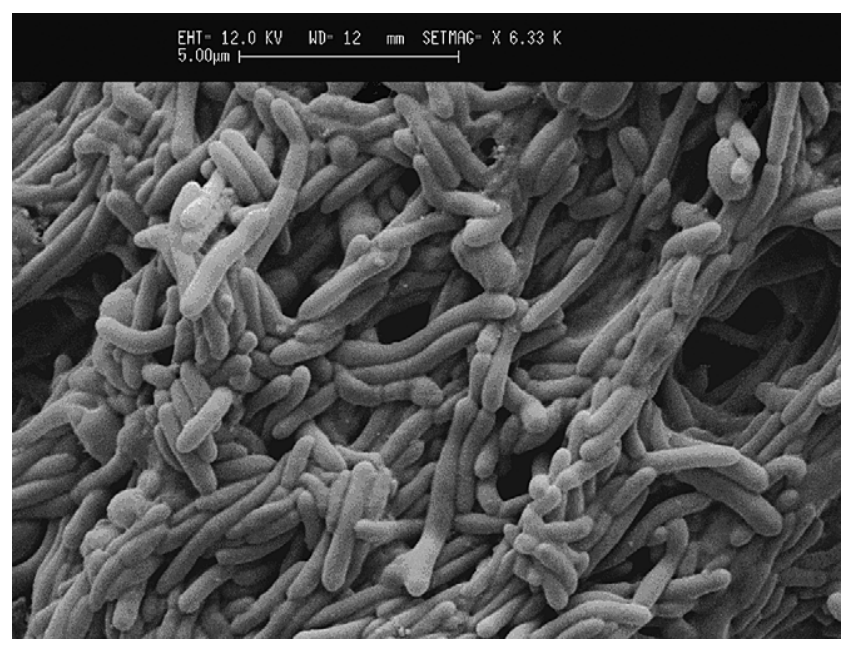

Fig. 1. Scanning electron microscopy photomicrograph of a 6 old B. cereus biofilm formed on a stainless steel surface. $\times 6330$ magnification; bar $=5 \mu \mathrm{m}$. spoilage of conventionally pasteurized milk during refrigerated storage (Dogan \& Boor, 2003; Wiedmann et al., 2000). Wong (1998) reported that undesirable microorganisms such as Lactobacillus curvatus and Lactobacillus fermentum persisted on milk residues in cheese processing plants even after repeated cleaning. Bacillus spp., particularly Bacillus cereus, are implicated in food spoilage (Andersson, Ronner, \& Granum, 1995; Janneke et al., 2007). In a commercial dairy plant $B$. cereus accounted for more than $12 \%$ of the biofilms constitutive microflora (Sharma \& Anand, 2002b). As $B$. cereus is ubiquitously present in nature, it is easily spread through food production systems, and contamination with this species is almost inevitable. Moreover, B. cereus spores are both highly resistant to a large number of stresses and very hydrophobic, which causes them to adhere easily to food processing equipment (Lindsay, Brözel, \& von Holy, 2006). Listeria spp. have been found in different places of dairy plants (Vilar, Yus, Sanjuan, Dieguez, \& Rodriguez-Otero, 2007; Waak et al., 2002). L. monocytogenes has been recognized as an important foodborne pathogen ever since an outbreak of listeriosis in Canada was linked to the consumption of contaminated coleslaw (Schlech et al., 1983). This bacterium is considered by many food hygienists as a major food safety challenge in the dairy industry. The psychrotrophic nature of L. monocytogenes allows replication in refrigerated ready-to-eat food products that were contaminated during processing and packaging. Consequently, $L$. monocytogenes is frequently associated with foodborne disease outbreaks that are characterized by widespread distribution and relatively high mortality rates (Borucki, Peppin, White, Loge, \& Call, 2003). This bacterium may also survive for a long time in dairy processing facilities. Unnerstad et al. (1996) found that $L$. monocytogenes persisted in a dairy processing facility for 7 years.

The time available for biofilm formation will depend on the frequency of cleaning and disinfection regimes. Product contact surfaces, such as the milking machines, may typically be cleaned several times per day, while environmental surfaces such as walls may only be cleaned once per day. Therefore, there is more time for biofilm formation on environmental surfaces. Gibson, Taylor, Hall, and Holah (1995) reported that, although attachment to a variety of surfaces in the food processing environment readily occurred, extensive surface colonization and biofilm formation occurred on environmental surfaces. Product contact surfaces may contaminate the product directly i.e. the product touching or passing over the surface will potentially pick up microbial contamination.

Effective control of undesirable biofilms can be achieved by understanding the type and nature of the contaminating residue materials (carbohydrates, fat, proteins, mineral salts) and the microorganisms to be removed from the surfaces. Furthermore, the selection of detergents and disinfectants depends on their efficacy, safety and ease of removal; specifically relating to the corrosive nature of the chemical treatments and the subsequent sensory value effects on the final products (Mosteller \& Bishop, 1993; Wirtanen, Saarela, \& Mattila-Sandholm, 2000). Greater residue removal in the pre-rinse steps aids further cleaning efforts by reducing the quantities of cleaning products used. The equipment design and choice of surface materials are important in preventing biofilm formation. The most practical material in processing equipment is steel, which can be treated with mechanical grinding, brushing, lapping, and electrolytic or mechanical polishing (Maukonen et al., 2003). A prerequisite for an efficient sanitation programme is that the process equipment has been designed with high standards of hygiene in mind. Dead ends, corners, cracks, crevices, gaskets, valves and joints are vulnerable points for biofilm accumulation (Chmielewski \& Frank, 2006). The most effective sanitation programme cannot make up for basic deficiencies in 
equipment design and if design faults exist sanitation can never be totally effective. Provided that the equipment and processing environment are hygienically designed (with no crevices, dead spaces, surface material, etc), an effective cleaning and disinfection programme is the main strategy to control surface route contaminations. An effective sanitation programme removes undesirable material from the surfaces, including microorganisms, residues, foreign bodies and residual cleaning products (Dosti, Guzel-Seydim, \& Greene, 2005).

Cleaning-in-place (CIP) procedures are usually employed in milk processing lines. The basic sequence of operations is: 1 . a prerinse with cold water to remove gross residues; 2 . the circulation of detergent to remove remaining minor residues; 3 . an intermediate cold water rinse to flush out detergent; 4 . the circulation of disinfectant to inactivate and kill any residual microorganisms; 5. a final cold water rinse to flush out detergent (Forsythe \& Hayes, 1998). Nevertheless, the limitation of CIP procedures still is the residual microorganisms on the equipment surfaces, resulting in biofilm formation (Bremer et al., 2006; Kumar \& Anand, 1998; Sharma \& Anand, 2002b). Dufour, Simmonds, and Bremer (2004) tested a CIP regime against dairy biofilms (water rinse, $1 \%$ sodium hydroxide at $70{ }^{\circ} \mathrm{C}$ for $10 \mathrm{~min}$, water rinse, $0.8 \%$ nitric acid at $70{ }^{\circ} \mathrm{C}$ for $10 \mathrm{~min}$, water rinse) followed by exposure to either chlorine or combinations of nisin, lauricidin and the lactoperoxidase system for defined exposure periods. This strategy was inefficient in the total biofilm control. The CIP regime provided significant variation in reducing the viable cell numbers (log reduction between 0 and 2 ). The additional antimicrobial treatment resulted in a maximum $\log$ reduction of 2.8 , verified $2 \mathrm{~h}$ after chlorine exposure. Bremer et al. (2006) also reported the inefficacy of a standard CIP regime (water rinse, $1 \%$ sodium hydroxide at $65{ }^{\circ} \mathrm{C}$ for $10 \mathrm{~min}, 1 \%$ nitric acid for $10 \mathrm{~min}$, water rinse) to remove bacteria attached to surfaces.

An independent quality control system to monitor the cleaning results for a dairy plant can be integrated in the Hazard Analysis Critical Control Points (HACCP) program. Evaluation of biofilm sanitation should be part of the HACCP development plan in order to control those biofilms prevalent in the processing areas (Sharma \& Anand, 2002b). Moreover, impairing the formation of biofilms can be achieved through a better knowledge of the mechanisms that contribute to their formation, development and maintenance (Simões, Sillankorva, Pereira, Azeredo, \& Vieira, 2007).

\section{Biofilm formation}

There are a number of mechanisms by which numbers of microbial species are able to come into closer contact with a surface, attach firmly to it, promote cell-cell interactions and grow as a complex structure (Breyers \& Ratner, 2004). Biofilm formation comprises a sequence of steps (Breyers \& Ratner, 2004). As biofilm formation mechanisms will only be discussed briefly, the reader is directed to several excellent comprehensive reviews on this area (Breyers \& Ratner, 2004; Chmielewski \& Frank, 2003; Donlan \& Costerton, 2002; Hall-Stoodley \& Stoodley, 2002; O’Toole, Kaplan, \& Kolter, 2000; Verstraeten et al., 2008).

At present, processes governing biofilm formation that have been identified include (Fig. 2): 1 . pre-conditioning of the adhesion surface either by macromolecules present in the bulk liquid or intentionally coated on the surface; 2 . Transport of planktonic cells from the bulk liquid to the surface; 3 . Adsorption of cells at the surface; 4 . Desorption of reversibly adsorbed cells; 5 . Irreversible adsorption of bacterial cells at a surface; 6 . Production of cell-cell signalling molecules; 7. Transport of substrates to and within the biofilm; 8 . Substrate metabolism by the biofilm-bound cells and transport of products out of the biofilm. These processes are accompanied by cell growth, replication, and EPS production; 9. Biofilm removal by detachment or sloughing (Breyers \& Ratner, 2004).

The attachment of microorganisms to surfaces and the subsequent biofilm development are very complex processes, affected by several variables (Table 1 ). In general, attachment will occur most readily on surfaces that are rougher, more hydrophobic, and coated by surface conditioning films (Chae, Schraft, Truelstrup, \& Mackereth, 2006; Donlan, 2002; Millsap, Reid, van der Mei, \& Busscher, 1997; Oulahal, Brice, Martial, \& Degraeve, 2008; Patel, Ebert, Ward, \& Anderson, 2007; Simões, Simões, Cleto, Pereira, \& Vieira, 2008). Properties of the cell surface, particularly the presence of extracellular appendages, the interactions involved in cell-cell communication and EPS production are important for biofilm formation and development (Allison, 2003; Davies et al., 1998; Donlan, 2002; Parsek \& Greenberg, 2005; Sauer \& Camper, 2001). An increase in flow velocity or nutrient concentration may also equate to increased attachment, if these factors do not exceed critical levels (Simões, Sillankorva, et al., 2007; Stoodley, Lewandowski, Boyle, \& Lappin-Scott, 1999; Vieira et al., 1993). The

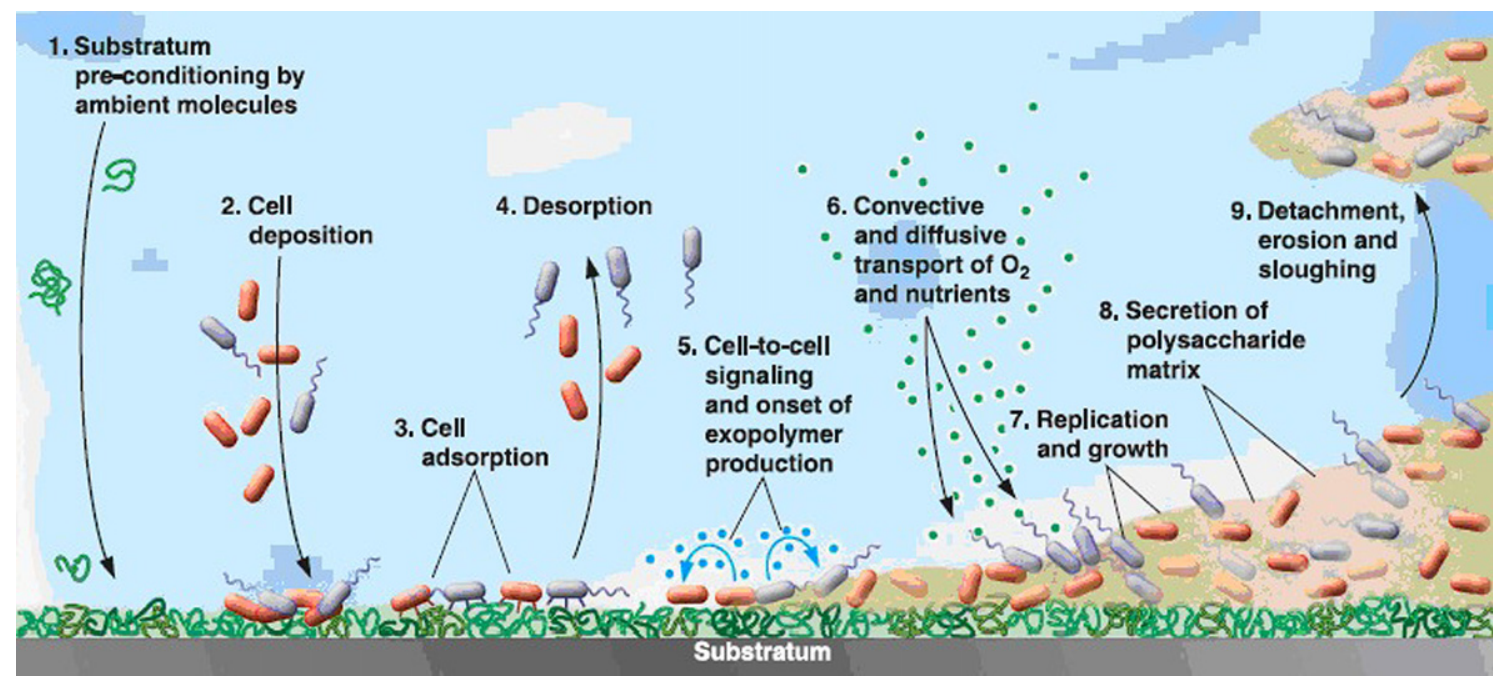

Fig. 2. Processes governing biofilm formation (Breyers \& Ratner, 2004). Courtesy from the American Society for Microbiology. 
Table 1

Variables important in cell attachment, biofilm formation and development (based on Donlan, 2002).

\begin{tabular}{|c|c|c|}
\hline Adhesion surface & Bulk fluid & Cell \\
\hline Texture or roughness & Flow velocity & Cell surface hydrophobicity \\
\hline Hydrophobicity & $\mathrm{pH}$ & Extracellular appendages \\
\hline Surface chemistry & Temperature & $\begin{array}{l}\text { Extracellular polymeric } \\
\text { substances }\end{array}$ \\
\hline Charge & Cations & Signalling molecules \\
\hline Conditioning film & $\begin{array}{l}\text { Presence of } \\
\text { antimicrobial products } \\
\text { Nutrient availability }\end{array}$ & \\
\hline
\end{tabular}

biological aspects regulating biofilm formation, referred in Table 1, will be briefly described in the following sections.

\subsection{Specialized attachment structures/surface properties of the cell}

Cell surface hydrophobicity and the presence of extracellular filamentous appendages may influence the rate and the extent of microbial attachment. The hydrophobicity of the cell surface is important in adhesion because hydrophobic interactions tend to increase with an increasing non-polar nature of one or both surfaces involved, i.e., the microbial cell and the adhesion surface (Donlan, 2002). According to Drenkard and Ausubel (2002), the ability of bacteria to attach to each other and to surfaces depends in part on the interaction of hydrophobic domains.

Many cells produce extracellular filamentous appendages. These may, therefore, play a role in the attachment process. In fact, their radius of interaction with the surface is far lower than that of the cell itself. A number of such structures are known to exist - flagella, pili or fimbrae, prothecae, stalks and hold-fast (Harbron \& Kent, 1988).

Flagella, when existent, are responsible for the motility of bacteria. These are very fine threads of the protein flagellin with a helical structure extending out from the cytoplasm through the cell wall. Flagella may have a diameter between 0.01 and $0.02 \mu \mathrm{m}$, and a length of up to $10 \mu \mathrm{m}$. Many types of bacteria have flagella, including the genus Pseudomonas. It is possible that the flagellum itself may form an adhesive bond with the adhesion surface (Harbron \& Kent, 1988). The primary function of flagella in biofilm formation is assumed to be in transport and in initial cell-surface interactions (Sauer \& Camper, 2001). Flagella-mediated motility is believed to overcome repulsive forces at the surface of the substratum and, as a consequence, a monolayer of cells forms on the adhesion surface (Daniels, Vanderleyden, \& Michiels, 2004).

Pili or fimbriae are found on many Gram-negative bacteria including Pseudomonas species. They are fine, filamentous appendages, also of protein, $4-35 \mathrm{~nm}$ wide and up to several micrometers long (Harbron \& Kent, 1988). These structures are usually straight, and are not involved in motility. Their only known general function is to make cells more adhesive, since bacteria with pili can adhere strongly to other bacterial cells and inorganic particles (Harbron \& Kent, 1988). Nevertheless, they are not always involved in the attachment process even if they are present (Characklis \& Cooksey, 1983). According to Sauer and Camper (2001), pili and pilus-associated structures have been shown to be important for the adhesion to and colonization of surfaces, probably by overcoming the initial electrostatic repulsion barrier that exists between the cell and the substratum.

Prosthecae and stalks form a third group of attachment structures. These occur in several types of microorganisms. They may occur at one or more sites on the cell surface, and are filiform or blunt extensions (commonly $0.2 \mu \mathrm{m}$ ) of the cell wall and membrane (Harbron \& Kent, 1988). At the end of a prosthecae or stalk is usually found an adhesive disk, or hold-fast. The stalk and hold-fast structure is quite often used by diatoms to attach to a surface (Harbron \& Kent, 1988).

\subsection{Extracellular polymeric substances (EPS)}

EPS are responsible for binding cells and other particulate materials together (cohesion) and to the surface (adhesion) (Allison, 2003; Characklis \& Wilderer, 1989; Sutherland, 2001). The general composition of bacterial EPS comprises polysaccharides, proteins, nucleic acids, lipids, phospholipids, and humic substances (Jahn \& Nielsen, 1998; Sutherland, 2001; Wingender, Neu, \& Flemming, 1999). According to Tsuneda, Aikawa, Hayashi, Yuasa, and Hirata (2003), proteins and polysaccharides account for $75-89 \%$ of the biofilm EPS composition, indicating that they are the major components.

Biofilms form a gel phase where microorganisms live inside (Sutherland, 2001; Wingender et al., 1999). The EPS matrix acts as a barrier in which diffusive transport prevails over convective transport (Sutherland, 2001). A function frequently attributed to EPS is their general protective effect on biofilm microorganisms against adverse conditions. As an example, it has frequently been observed that biofilm cells can tolerate high concentrations of biocides (Foley \& Gilbert, 1996; Mah \& O’Toole, 2001; Simões \& Vieira, 2009; Simões, Pereira, \& Vieira, 2005). This is supposed to be due mainly to physiological characteristics of biofilm bacteria, but also to a barrier function of EPS (Morton, Greenway, Gaylarde, \& Surman, 1998; Simões et al., 2005). The EPS matrix delays or prevents antimicrobials from reaching target microorganisms within the biofilm by diffusion limitation and/or chemical interaction with the extracellular proteins and polysaccharides (Heinzel, 1998; Mah \& O'Toole, 2001). Moreover, within the EPS matrix the molecules required for cell-cell communication and community behavior may accumulate at concentrations high enough to be effective (Pearson, Delden \& Iglewski, 1999;Sutherland, 2001).

The role of EPS components other than polysaccharides and proteins (fundamental structural elements of the biofilm matrix determining the mechanical stability of biofilms) remains to be established (Wingender et al., 1999). Bacterial alginates represent an example of the few EPS which have been studied in detail, however, under the aspects of their relevance as a general virulence factor in infection processes of plants, animals, and man as well as in terms of their potential commercial exploitation (Wingender et al., 1999). Lipids and nucleic acids might significantly influence the rheological properties and thus the stability of biofilms (Neu, 1996). The extracellular DNA is required for the initial establishment of biofilms by Pseudomonas aeruginosa, and possibly for biofilms formed by other bacteria that specifically release DNA (Whitchurch, Tolker-Nielsen, Ragas, \& Mattick, 2002).

\subsection{Cell-cell communication}

The driving force in bacterial community development is the self-organization and cooperation among cells, rather than the classical "competitive" natural selection of individual microorganisms (Daniels et al., 2004; Davies et al., 1998; Fuqua \& Greenberg, 2002; Parsek \& Greenberg, 2005). This concept becomes particularly apparent when examining bacterial biofilm communities (Parsek \& Greenberg, 2005; Surette, Miller, \& Bassler, 1999). Cellcell signalling has been demonstrated to play a role in cell attachment and detachment from biofilms (Daniels et al., 2004; Donlan, 2002). Bacteria are considered to be far from solitary microorganisms, and in fact are colonial by nature and exploit elaborate 
systems of intercellular interactions and communications to facilitate their adaptation to changing environments (Davies et al., 1998; Fuqua \& Greenberg, 2002; Sauer \& Camper, 2001). The successful adaptation of bacteria to changing natural conditions is dependent on their ability to sense and respond to the external environment and modulate gene expression accordingly (Daniels et al., 2004). Quorum sensing is based on the process of autoinduction (Eberhard et al., 1981). The process of quorum sensing provides a mechanism for self-organization and regulation of microbial cells (Parsek \& Greenberg, 2005). It involves an environmental sensing system that allows bacteria to monitor and respond to their own population densities. The bacteria produce a diffusible organic signal, originally called an auto-inducer (AI) molecule, which accumulates in the surrounding environment during growth (Fuqua \& Greenberg, 2002). High cell densities result in high concentrations of signal, and induce expression of certain genes and/or physiological changes in neighbouring cells (Fuqua, Winans, \& Greenberg, 1996; Parsek \& Greenberg, 2005). A response to chemical signals in the process of cell communication is a concentration dependent process, where a critical threshold concentration of the signal molecule must be reached before a physiological response is elicited (Decho, 1999; Fuqua \& Greenberg, 2002). Oligopeptides and $\mathrm{N}$-acylhomoserine lactones (AHL) are major AI molecules involved in intra-specific communication in Gram-positive and Gram-negative bacteria, respectively, whereas boronated diester molecules (AI-2) are involved in inter-specific communication among both Gram-positive and Gram-negative bacteria (Eberhard et al., 1981; Fuqua \& Greenberg, 2002; Parsek \& Greenberg, 2005). AHL (AI-1) are the best characterized molecules (Eberhard et al., 1981; Ryan \& Dow, 2008).

Quorum sensing systems are known to be involved in a range of important microbial activities. These include extracellular enzyme biosynthesis, biofilm development, antibiotic biosynthesis, biosurfactant production, EPS synthesis and extracellular virulence factors in Gram-negative bacteria (Beck von Bodman \& Farrand, 1995; Daniels et al., 2004; Davies et al., 1998; Fux, Costerton, Stewart, \& Stoodley, 2005; Passador, Cook, Gambello, Rust, \& Iglewski, 1993; Pearson, Passador, Iglewski, \& Greenberg, 1995).

\section{Approach for biofilm mitigation - biofilm prevention}

Ideally, preventing biofilm formation would be a more logical option than treating it. However, there is presently no known technique that is able to successfully prevent or control the formation of unwanted biofilms without causing adverse side effects. The main strategy to prevent biofilm formation is to clean and disinfect regularly before bacteria attach firmly to surfaces (Midelet \& Carpentier, 2004; Simões et al., 2006). Biofilm detectors were already developed to monitor the surface colonization by bacteria and allow the control of biofilms in the early stages of development (Pereira, Mendes, \& Melo, 2008; Philip-Chandy et al., 2000). Pereira et al. (2008) developed a mechatronic surface sensor able to detect biofilms in the early stages of development. This sensor was also able to detect the presence of cleaning products in a surface, identify when it was biologically and chemically cleaned and measure the rate of cleaning (Pereira, Mendes, \& Melo, 2009). Other preventive strategies attempted to identify materials that do not promote or can even suppress biofilm formation (Rogers, Dowsett, Dennis, Lee, \& Keevil, 1994). This study ranked different materials according to their biofilm growth propensity concluding that there is hardly any material that does not allow biofilm formation (Rogers et al., 1994). Moreover, biofilm formation may vary with the microbial species present and with the environmental conditions (Simões, Simões, \& Vieira, 2007). Frank and Chmielewski (2001) tested the influence of surface finish on the ease of cleaning of stainless steel soiled with either cultured milk inoculated with spores of Bacillus stearothermophilus or by growth of Pseudomonas sp. biofilms. The research conclusions indicated a higher significance of surface defects/roughness on the ease of surface cleaning rather than the surface finishing type.

Inhibition of biofilm formation by limitation of the carbon source is a virtually impossible procedure, as ultra-pure water systems have been found to support the formation of biofilms (Griebe \& Flemming, 1998). Another approach is to supply the microorganisms with growth factors, so surface attachment is no more a benefit for them (Meyer, 2003).

Several attempts have been made to avoid biofilm formation by the incorporation of antimicrobial products into surface materials (Park, Daeschel, \& Zhao, 2004; Weng, Chen, \& Chen, 1999), by coating surfaces with antimicrobials (Gottenbos, van der Mei, Klatter, Nieuwenhuis, \& Busscher, 2001; Thouvenin et al., 2003; Tsibouklis et al., 2000) or by modifying the surfaces physicochemical properties (Rosmaninho et al., 2007; Whitehead, Collingon, \& Verran, 2004, 2005). Gottenbos et al. (2001) demonstrated a reduction in infection rate using silicone rubber implants with covalently coupled quaternary ammonium coatings. Other authors reported biofilm formation inhibition by coating surfaces with silver (Hashimoto, 2001; Klueh, Wagner, Kelly, Johnson, \& Bryers, 2000). These studies focused on biomedical applications but the approaches may also be useful in the dairy industry if restricted to some parts of the process equipment such as valves, dead ends or where biofilms are more prone to form and difficult to control. In fact, possible carry over of antimicrobials into food products is a concern when coatings release antimicrobial products.

Cloete and Jacobs (2001) reported that surface pre-conditioning with surfactants has potential to prevent bacterial adhesion. Nonionic and anionic surfactants were evaluated in preventing the adhesion of $P$. aeruginosa to stainless steel and glass surfaces. The surfactants gave more than $90 \%$ inhibition of adhesion. More recently, other studies (Meylheuc, Renault, \& Bellon-Fontaine, 2006; Pereira et al., 2006; Splendiani, Livingston, \& Nicolella, 2006) reinforced the efficiency of surfactants and surface pre-conditioning on biofilm formation control. Splendiani et al. (2006) screened 22 surfactants for their potential to increase the cell wall charge of a Burkholderia sp. strain and reduce the ability to attach and form biofilms. The authors demonstrated that some surfactants affected the development of flagella, demonstrating significant changes in the bacteria attachment ability in the presence of surfactants.

\section{Cleaning and disinfection}

In the dairy industry the classical operations of cleaning and disinfection are essential parts of milk production. The efficiency with which these operations are performed greatly affects the final product quality (Bremer et al., 2006; Sharma \& Anand, 2002b). Generally, disinfectants do not penetrate the biofilm matrix left on a surface after an ineffective cleaning procedure, and thus do not destroy all the biofilm living cells (Simões et al., 2006). Therefore, cleaning is the first step and of utmost importance to improve the sanitation of the processing equipment (Forsythe \& Hayes, 1998). It is important to effectively remove food debris and other residues that may contain microorganisms or promote microbial growth. The use of high temperature can reduce the need for the application of physical forces such as water turbulence and scrubbing (Maukonen et al., 2003). Chemical products commonly used for cleaning are surfactants or alkali products, used to suspend and dissolve food residues by decreasing surface tension, emulsifying fats, and denaturing proteins (Forsythe \& Hayes, 1998; Maukonen et al., 2003; Mosteller \& Bishop, 1993). These chemicals are currently used as combinations. Many situations in dairy processing plants 
require the occasional use of acid cleaners for surfaces soiled with precipitated minerals or having high food residue/mineral content, such as milkstone. Mechanical action is recognized as being highly effective in eliminating biofilms (Srinivasan, Stewart, Griebe, Chen, $\& \mathrm{Xu}, 1995)$. An effective cleaning procedure must break up or dissolve the EPS matrix associated with the biofilms so that disinfectants can gain access to the viable cells (Simões et al., 2006). The cleaning process can remove $90 \%$ or more of microorganisms associated with the surface, but cannot be relied upon to kill them. Bacteria can redeposit at other locations and given time, water and nutrients can form a biofilm. Therefore, disinfection must be implemented (Gram et al., 2007). Another drawback of a cleaning process is that it is often impractical and can be costly because it usually involves equipment downtime (Jessen \& Lammert, 2003; Srinivasan et al., 1995).

Disinfection is the use of antimicrobial products to kill microorganisms. The aim of disinfection is to reduce the surface population of viable cells left after cleaning and prevent microbial growth on surfaces before production restart. Disinfectants are more effective in the absence of organic material (fat, carbohydrates, and protein based materials). Interfering organic substances, $\mathrm{pH}$, temperature, water hardness, chemical inhibitors, concentration and contact time generally control the disinfectants efficacy (Bremer, Monk, \& Butler, 2002; Cloete, Jacobs, \& Brozel, 1998; Kuda, Yano, \& Kuda, 2008).

The disinfectants must be effective, safe and easy to use, and easily rinsed off from surfaces, leaving no toxic residues that could affect the health properties and sensory values of the final products. Nevertheless, the literature demonstrates that there is no one strategy with absolute biofilm control efficiency. Mosteller and Bishop (1993), evaluated the efficacy of conventional antimicrobial products (iodophor, hypochlorite, acid anionic, peroxyacetic acid, fatty acid and quaternary ammonium compound sanitizers) on bacteria attached to gasket materials made of rubber and Teflon. A significant reduction in the number of attached $Y$. enterocolitica was only reached on Teflon surfaces treated with iodophor, hypochlorite and fatty acid sanitizers. A significant reduction in the number of attached Pseudomonas fluorescens was achieved for both surfaces when exposed to hypochlorite sanitizer. Another study published 16 years ago (Greene, Few, \& Serafini, 1993) already described the high efficacy (bacteria population reduction $>99 \%$ ) of ozone and a commercial chlorinated sanitizer to control $P$. fluorescens and Alcaligenes faecalis biofilms. However, in a biofilm control process the residual viable population, even if lower than $1 \%$ of the total population can reseed the biofilm.

The selection of disinfectants to be used in a dairy processing plant depends on the material of the processing equipment used and on the adhering microorganisms. The chemicals currently used in disinfection processes belong to the following types: acidic compounds, aldehyde-based biocides, caustic products; chlorine, hydrogen peroxide, iodine, isothiazolinones, ozone, peracetic acid, phenolics, biguanidines, surfactants (Bremer et al., 2006; Dosti et al., 2005; Rossmore, 1995; Simões et al., 2006; Wirtanen et al., 2000). Table 2 shows representative antimicrobial strategies used to control biofilms formed by bacteria commonly found in dairy processing plants.

It is important to note that most of the disinfection processes that are implemented are based upon the results of planktonic tests (European Standard - EN 1276, 1997). However, such tests do not mimic the behavior of biofilm cells and can be highly ineffective when applied to control biofilms. Biofilms have been reported as possessing susceptibilities towards antimicrobials that are 100-1000 times less than equivalent populations of free-floating counterparts (Gilbert, Allison, \& McBain, 2002). If a microbial population faces high concentrations of an antimicrobial product, susceptible cells will be inactivated. However, some cells may possess a degree of natural resistance and physiological plasticity or they may acquire it later through mutation or genetic exchange. These processes allow the microorganism to survive and grow (Davies, 2003; Gilbert \& McBain, 2003; Mah \& O’Toole, 2001; McBain, Rickard, \& Gilbert, 2002). The increased biofilm resistance to conventional treatments enhances the need to develop new control strategies (Simões, Bennett, \& Rosa, 2009; Singh et al., 2002).

\section{The green strategy for biofilms control - enzymes, phages and bioregulation}

\subsection{Enzyme-based detergents}

The use of enzyme-based detergents as bio-cleaners, also known as "green chemicals", can serve as a viable option to overcome the biofilm problem in the food industry. Due to the EPS heterogeneity, a mixture of enzymes may be necessary for sufficient biofilm degradation. Augustin, Ali-Vehmas, and Atroshi

Table 2

Antimicrobial products applied to control biofilms formed by bacteria commonly found in dairy processing plants.

\begin{tabular}{|c|c|c|}
\hline Treatment & Biofilm type & Reference \\
\hline Ozone, commercial chlorinated sanitizer & P. fluorescens/Alcaligenes faecalis & Greene et al. (1993) \\
\hline $\begin{array}{l}\text { Benzalkonium chloride, hexadecyl trimethylammonium } \\
\text { bromide, sodium hypochlorite, peracetic acid, } \\
\text { hydrogen peroxide, } 0 \text {-cresol, phenol }\end{array}$ & E. coli & $\begin{array}{l}\text { Ntsama-Essomba, Boutier, Ramaldes, } \\
\text { Dubois-Brissonet, and Fourniat (1997) }\end{array}$ \\
\hline Chlorine, peracetic acid, peroctanoic acid & $\begin{array}{l}\text { L. monocytogenes and Pseudomonas } \\
\text { sp. mixed biofilms }\end{array}$ & Fatemi and Frank (1999) \\
\hline Chlorine dioxide containing sanitizer & $\begin{array}{l}\text { B. cereus/P. fluorescens single and } \\
\text { mixed biofilms }\end{array}$ & Lindsay, Brözel, Mostert, and Von Holy (2002) \\
\hline Chlorine & E. coli & Lomander et al. (2004) \\
\hline $\begin{array}{l}\text { Chlorinated-alkaline solution; low-phosphate buffer detergent; } \\
\text { dual peracid solution; alkaline solution; hypochlorite }\end{array}$ & L. monocytogenes & Somers and Wong (2004) \\
\hline Sodium hydroxide; commercial alkaline cleaner & P. putida & Antoniou and Frank (2005) \\
\hline Chorine; ozone & P. fluorescens, $P$. fragi and P. putida & Dosti et al. (2005) \\
\hline Chlorine, hydrogen peroxide, ozone & L. monocytogenes & Robbins, Fisher, Moltz, and Martin (2005) \\
\hline $\begin{array}{l}\text { Glutaraldehyde, ortho-phtalaldehyde, hexadecyl } \\
\text { trimethylammonium bromide, sodium dodecyl } \\
\text { sulfate, chlorine solution sodium hydroxide }\end{array}$ & P. fluorescens & Simões et al. (2005) \\
\hline Sodium hydroxide; nitric acid & Mixed species & Bremer et al. (2006) \\
\hline Chlorine; chlorine dioxide; commercial detergent & B. cereus and Pseudomonas spp. & Kreske, Ryu, Pettigrew, and Beuchat (2006) \\
\hline Sodium hypochlorite & S. typhimurium & Lapidot et al. (2006) \\
\hline Peroxydes; quaternarium ammonium compounds; chlorine & L. monocytogenes & Pan, Breidt, and Kathariou (2006) \\
\hline Hydrogen peroxide; sodium dichloroisocyanurate; peracetic acid & Staph. aureus & Marques et al. (2007) \\
\hline
\end{tabular}


(2004) demonstrated the potential application of enzymatic cleaning products against biofilms formed by microorganisms commonly found in dairy products (Lactobacillus bulgaricus, Lactobacillus lactis, Streptococcus thermophilus). However, the performance of the enzyme action was significantly reduced in the presence of milk, particularly proteolytic enzymes. Oulahal-Lagsir, Martial-Gros, Bonneau, and Blum (2003) found interesting results when synergistically applying ultrasonic waves and proteolytic and glycolytic enzymes against stainless steel attached $E$. coli biofilms developed with milk. A 10 s treatment resulted in removal amounts between 61 and $96 \%$ of the total biofilm. Enzymes and detergents have also been used as synergists to improve disinfectant efficacy (Jacquelin et al., 1994; Johansen, Falholt, \& Gram, 1997; Parkar, Flint, \& Brooks, 2004). The combination of proteolytic enzymes with surfactants increased the wetability of biofilms formed by a thermophylic Bacillus species and, therefore, enhanced the cleaning efficiency (Parkar et al., 2004). Jacquelin et al. (1994) also reported the synergistic action of enzymes in combination with surfactants and phenolic antimicrobials.

The specificity in the enzymes mode of action makes it a complex technique, increasing the difficulty of identifying enzymes that are effective against all the different types of biofilms. Formulations containing several different enzymes seem to be fundamental for a successful biofilm control strategy. Basically, proteases and polysaccharide hydrolysing enzymes may be useful (Meyer, 2003). Moreover, the use of enzymes in biofilm control is still limited due to the low prices of the chemicals used today compared with the costs of the enzymes. In fact, the technology and production of these enzymes and the enzyme-based detergents are mostly patent-protected. Moreover, the low commercial accessibility of different enzyme activities limits their current usage (Johansen et al., 1997).

\subsection{Control using phages}

Phages are ubiquitous in nature. Bacteriophages are viruses that infect bacteria and may provide a natural, highly specific, non-toxic, feasible approach for controlling several microorganisms involved in biofilm formation (Kudva, Jelacic, Tarr, Youderian, \& Hovde, 1999). The technology for this has not yet been successfully developed and relatively little information is available on the action of bacteriophages on biofilms (Hughes, Sutherland, Clark, \& Jones, 1998; Sillankorva, Oliveira, Vieira, Sutherland, \& Azeredo, 2004; Sutherland, Hughes, Skillman, \& Tait, 2004). Moreover, the infection of biofilm cells by phages is extremely conditioned by their chemical composition and the environmental factors, such as temperature, growth stage, media and phage concentration (Chaignon et al., 2007; Sillankorva et al., 2004).

When phages come into contact with biofilms, further interactions occur, depending on the susceptibility of the biofilm cells to the phage and to the availability of receptor sites. If the phage also possesses polysaccharide-degrading enzymes, or if considerable cell lysis is affected by the phage, the integrity of the biofilm may rapidly be destroyed. Hughes, Sutherland, and Jones (1998) working in the control of Enterobacter agglomerans biofilms by the use of phages found that cells were lysed and the biofilms were degraded by the bacteriophage. The phage then lysed the biofilm cells, the polysaccharide polymerase enzyme degraded the EPS and caused biofilm sloughoff. However, if only one of these criteria was met, there was still a substantial degree of biofilm degradation and coexistence between phage and host bacteria (Hughes, Sutherland, et al., 1998). Sillankorva et al. (2004) used bacteriophages to eliminate $P$. fluorescens cells, showing that phages were efficient in the removal of biofilms in the early stage of development and 5 days old biofilms (up to $80 \%$ of biofilm removal), under optimal conditions. In $P$. aeruginosa biofilms the bacteriophage migration through the biofilms is facilitated by the reduction in alginate viscosity. This phenomenon is apparently related to the exopolysaccharide degradation by enzymes produced by the bacterial host (Hanlon, Denyer, Ollif, \& Ibrahim, 2001). A bacteriophage (L. monocytogenes phage ATCC 23074-B1) was used successfully in $L$. monocytogenes biofilm inactivation (Hibma, Jassim, \& Griffiths, 1997). E. coli biofilms have been shown to be susceptible to bacteriophage T4 (Doolittle, Cooney, \& Caldwell, 1995). Sharma, Ryu, and Beuchat (2005) reported the synergistic effect of an alkaline cleaner and a bacteriophage in the inactivation of $E$. coli 0157:H7 biofilms formed on stainless steel. More recently, Lu and Collins (2007) engineered a bacteriophage to express a biofilm degrading enzyme. This enzymatic phage had the ability to attack the bacterial cells in the biofilm and the biofilm matrix, substantially reducing the biofilm cell counts (more than $99.9 \%$ of removal).

\subsection{Control through microbial interactions/metabolite molecules}

The existence of multiple interspecies interactions or the simple production of a metabolite can interfere with biofilm formation and development (Carpentier \& Chassing, 2004; Kives et al., 2005; Røssland, Langsrud, Granum, \& Sørhaug, 2005; Tait \& Sutherland, 1998; Valle et al., 2006). Competition for substrates is considered to be one of the major evolutionary driving forces in the bacterial world, and numerous experimental data obtained in the laboratory, under controlled conditions, show how different microorganisms may effectively out-compete others because of their better utilization of a given energy source (Christensen, Haagensen, Heydorn, \& Molin, 2002; Simões, Simões, et al., 2007). Some authors (Leriche \& Carpentier, 2000; Zhao, Doyle, \& Zhao, 2004) found that biofilmforming microorganisms from surfaces in dairy processing facilities could play a role by interfering with the biological activities of pathogenic bacteria. Many bacteria are capable of synthesizing and excreting biosurfactants with anti-adhesive properties (Desai \& Banat, 1997; Nitschke \& Costa, 2007; Rodrigues, van der Mei, Teixeira, \& Oliveira, 2004; van Hamme, Singh, \& Ward, 2006). Biosurfactants produced by Lactococcus lactis 53 impaired biofilm formation on silicone rubber (Rodrigues et al., 2004). Surfactin from Bacillus subtilis disperses biofilms without affecting cell growth and prevents biofilm formation by microorganisms such as Salmonella enterica, E. coli, and Proteus mirabilis (Mireles, Toguchi, \& Harshey, 2001). Other biosurfactants demonstrated biofilm control potential (Davey, Caiazza, \& O’Toole, 2003; Walencka, Różalska, Sadowska, \& Różalska, 2008; Rivardo, Turner, Allegrone, Ceri, \& Martinotti, 2009). Microbial molecules, commonly used as biopreservatives, such as nisin, lauricidin, reuterin and pediocin, have been well documented for their biofilm control potential against microorganisms commonly found in dairy processing facilities, including L. monocytogenes (Dufour et al., 2004; Garcia-Almendarez, Cann, Martin, Guerrero-Legarreta, \& Regalado, 2008; Mahdavi, Jalali, \& Kermanshahi, 2007; Zhao et al., 2004). Valle et al. (2006) demonstrated that $E$. coli expressing group II capsules release a soluble polysaccharide into their environment that induces physicochemical surface alterations, which prevent biofilm formation by a wide range of Gram-positive and Gram-negative bacteria. More recently, Davies and Marques (2009) found that $P$. aeruginosa produces cis-2decenoic acid, which is capable of inducing the dispersion of established biofilms and of inhibiting biofilm development. This molecule was effectively tested, when applied exogenously, against B. subtilis, E. coli, Staphylococcus aureus, Klebsiella pneumoniae, P. aeruginosa, P. mirabilis, Streptococcus pyogenes and the yeast Candida albicans. The authors also suggested that this molecule is functionally and structurally related to the class of short-chain fatty acid signalling molecules. 
Production of siderophores is a virulence factor in many microorganisms, acting as biocontrol molecules (Gram, Melchiorsen, Spanggaard, Huber, \& Nielsen, 1999). A pioneer study indicated that siderophore-containing Pseudomonas spp. culture supernatants inhibited growth of Shewanella putrefacians, as did the addition of iron-chelators (Gram, 1993). Such biological mechanisms, alone or as part of synergistic procedures could provide a new line of efficient biofilm control strategies (Banin, Vasil, \& Greenberg, 2005; Musk, Banko, \& Hergenrother, 2005; Singh, Parsek, Greenberg, \& Welsh, 2002). In the particular case of L. monocytogenes, iron availability affects several bacterial properties. An iron-deficient growth leads to a decrease in this bacterium surface hydrophobicity, together with major alterations in the surface protein composition (Conte et al., 1996). Moreover, the capacity of iron to influence bacterial growth depends not only on its concentration, but also on the bacterial species themselves. Ironbinding proteins, such as lactoferrins (mammalian non-imnune natural defenses), have been found to have bacteriostatic activity. These proteins are able to hinder the growth of E. coli and S. typhimurium (Valenti \& Antonini, 2005). This ability is based on their iron sequestration properties, making iron unavailable for bacteria. Nevertheless, an increase in iron availability will reverse the bacteriostatic activity and consequently allow bacteria to resume growth. According to the generally accepted definition, siderophores are ferric-specific microbial iron-chelator products whose biosynthesis is regulated by the availability of iron in the surrounding medium and under conditions of high iron concentrations, the production of these molecule is repressed (Machuca \& Milagres, 2003). Iron $\mathrm{Fe}^{3+}$ ions have a very low solubility at neutral $\mathrm{pH}$ and, therefore, cannot be used by some microorganisms. Siderophores dissolve these ions, essential for microbial survival, microbial interactions and biofilm formation, as soluble $\mathrm{Fe}^{3+}$ complexes that can be taken up by active transport mechanisms (Banin et al., 2005).

The discovery that many bacteria use quorum sensing to form biofilms makes it an attractive target for their control (Dunstall, Rowe, Wisdom, \& Kilpatrick, 2005; Rasmussen et al., 2005). It is conceivable that quorum sensing inhibition may represent a natural, widespread, antimicrobial strategy with significant impact on biofilm formation (Dong, Gusti, Zhang, Xu, \& Zhang, 2002). A good understanding of the cell-cell signalling phenomenon of bacteria such as L. monocytogenes can be used to control the biofilm formation process by the identification of products that can act as quorum sensing antagonists (Simões et al., 2009; Smith, Fratamico, \& Novak, 2004). This property can lead to the development of new and efficient natural products for biofilm control.

\section{Conclusions}

Microbial control in food processing has the main aims of reduction/eradication of microbes and their activity, and the prevention/control of the formation of biological deposits on the process equipment. Nowadays, the most efficient practical means for limiting microbial growth includes good production hygiene, a rational running of the process line, and effective use of cleaning and disinfectant products. Due to the increased resistance of biofilms to conventional disinfection processes, novel means for their control are constantly sought through the control of environmental factors on the process line and the use of new control strategies.

Much more needs to be learned about the impact of antimicrobial products on microbial biofilms and their recovery responses to damage, as microorganisms can develop resistance and subsequently survive previously effective control procedures. The discovery of new biofilm control strategies, following the specifications needed to be used in food industry, and based on the use of biological-based solutions with high antimicrobial activity and specificity seem to be a step ahead in overcoming the biofilm resistance issue.

\section{Acknowledgements}

The authors acknowledge the financial support provided by the Portuguese Foundation for Science and Technology (Project Bioresist - PTDC/EBB-EBI/105085/2008; PhD grant SFRH/BD/31661/ 2006 - Lúcia C. Simões). The authors would like to thank Dr. Richard Niel Bennett, CITAB-University of Trás-os-Montes e Alto Douro, for help with some aspects of the revision of this manuscript.

\section{References}

Aarnela, K., Lundén, J., Korkeala, H., \& Wirtanen, G. (2007). Susceptibility of Listeria monocytogenes strains to disinfectants and chlorinated alkaline cleaners at cold temperatures. LWT - Food Science and Technology, 40, 1041-1048.

Allison, D. G. (2003). The biofilm matrix. Biofouling, 19, 139-150.

Andersson, A., Ronner, U., \& Granum, P. E. (1995). What problems does the food industry have with the spore-forming pathogens Bacillus cereus and Clostridium perfringens? International Journal of Food Microbiology, 28, 145-155.

Antoniou, A., \& Frank, J. F. (2005). Removal of Pseudomonas putida and associated extracellular polymeric substances from stainless steel by alkali cleaning. Journal of Food Protection, 68, 277-281.

Augustin, M., Ali-Vehmas, T., \& Atroshi, F. (2004). Assessment of enzymatic cleaning agents and disinfectants against bacterial biofilms. Journal of Pharmacy and Pharmaceutical Sciences, 18, 55-64.

Austin, J. W., \& Bergeron, G. (1995). Development of bacterial biofilms in dairy processing plants. Journal of Dairy Research, 62, 509-519.

Banin, E., Vasil, M. L., \& Greenberg, P. (2005). Iron and Pseudomonas aeruginosa biofilm formation. Proceedings of the National Academy of Sciences USA, 102 11076-11081.

Beck von Bodman, S., \& Farrand, S. K. (1995). Capsular polysaccharide biosynthesis and pathogenicity in Erwinia stewartii require induction by an $\mathrm{N}$-acylhomoserine lactone autoinducer. Journal of Bacteriology, 177, 5000-5008.

Borucki, M. K., Peppin, J. D., White, D., Loge, F., \& Call, D. R. (2003). Variation in biofilm formation among strains of Listeria monocytogenes. Applied and Environmental Microbiology, 69, 7336-7342.

Bremer, P. J., Fillery, S., \& McQuillan, A. J. (2006). Laboratory scale clean-in-place (CIP) studies on the effectiveness of different caustic and acid wash steps on the removal of dairy biofilms. International Journal of Food Microbiology, 106, 254-262.

Bremer, P. J., Monk, I., \& Butler, R. (2002). Inactivation of Listeria monocytogenes/ flavobacterium spp. biofilms using chlorine: impact of substrate, $\mathrm{pH}$, time and concentration. Letters in Applied Microbiology, 35, 321-325.

Breyers, J. D., \& Ratner, J. P. (2004). Bioinspired implant materials befuddle bacteria ASM News, 70, 232-237.

Carpentier, B., \& Chassing, D. (2004). Interactions in biofilms between Listeria monocytogenes and resident microorganisms from food industry premises. International Journal of Food Microbiology, 97, 111-122.

Chae, M. S., Schraft, H., Truelstrup, L., \& Mackereth, R. (2006). Effects of physicochemical surface characteristics of Listeria monocytogenes strains on attachment to glass. Food Microbiology, 23, 250-259.

Chaignon, P., Sadovskaya, I., Ragunah, Ch., Ramasubbu, N., Kaplan, J. B., \& Jabbouri, S. (2007). Susceptibility of staphylococcal biofilms to enzymatic treatments depends on their chemical composition. Applied Microbiology and Biotechnology, $75,125-132$.

Characklis, W. G., \& Cooksey, K. E. (1983). Biofilms and microbial fouling. Advances in Applied Microbiology, 29, 93-138.

Characklis, W. G., \& Wilderer, P. A. (1989). Glossary. In W. G. Characklis, \& P. A. Wilderer (Eds.), Structure and function of biofilms (pp. 369-371).

Chen, J., Rossman, M. L., \& Pawar, D. M. (2007). Attachment of enterohemorragic Escherichia coli to the surface of beef and a culture medium. LWT - Food Science and Technology, 40, 249-254.

Chmielewski, R. A. N., \& Frank, J. F. (2003). Biofilm formation and control in food processing facilities. Comprehensive Reviews in Food Science and Food Safety, 2, 22-32.

Chmielewski, R. A. N., \& Frank, J. F. (2006). A predictve model for heat inactivation of Listeria monocytogenes biofilm on buna-N rubber. LWT - Food Science and Technology, 39, 11-19.

Christensen, B. B., Haagensen, J. A. J., Heydorn, A., \& Molin, S. (2002). Metabolic commensalism and competition in a two-species microbial consortium. Applied and Environmental Microbiology, 68, 2495-2502.

Cloete, T. E., \& Jacobs, L. (2001). Surfactants and the attachment of Pseudomonas aeruginosa to 3CR12 stainless steel and glass. Water SA, 27, 21-26.

Cloete, T. E., Jacobs, L., \& Brozel, V. S. (1998). The chemical control of biofouling in industrial water systems. Biodegradation, 9, 23-37. 
Conte, M. P., Longhi, C., Polidoro, M., Petrone, G., Buonfiglio, V., Di Santo, S., et al (1996). Iron availability affects entry of Listeria monocytogenes into the enterocytelike cell line Caco-2. Infection and Immunity, 64, 3925-3929.

Daniels, R., Vanderleyden, J., \& Michiels, J. (2004). Quorum sensing and swarming migration in bacteria. FEMS Microbiology Reviews, 28, 261-289.

Davey, M. E., Caiazza, N. C., \& O'Toole, G. A. (2003). Rhamnolipid surfactant production affects biofilm architecture in Pseudomonas aeruginosa PAO1. Journal of Bacteriology, 185, 1027-1036.

Davies, D. (2003). Understanding biofilm resistance to antibacterial agents. Nature Reviews in Drug Discovery, 2, 114-122.

Davies, D. G., \& Marques, C. N. (2009). A fatty acid is responsible for inducing dispersion in microbial biofilms. Journal of Bacteriology, 191, 1393-1403.

Davies, D. G., Parsek, M. R., Pearson, J. P., Iglewski, B. H., Costerton, J. W., \& Greenberg, E. P. (1998). The involvement of cell-to-cell signals in the development of a bacterial biofilm. Science, 280, 295-298.

Decho, A. W. (1999). Chemical communication within microbial biofilms: chemotaxis and quorum sensing in bacterial cells. In J. Wingender, T. R. Neu, \& H.-C. Flemming (Eds.), Microbial extracellular polymeric substances - Characterization, structure and function (pp. 155-170).

Desai, J. D., \& Banat, I. M. (1997). Microbial production of surfactants and their commercial potential. Microbiology and Molecular Biology Reviews, 61, 47-64.

Dogan, B., \& Boor, K. J. (2003). Genetic diversity and spoilage potential among Pseudomonas spp. isolated from fluid milk products and dairy processing plants. Applied and Environmental Microbiology, 69, 130-138.

Dong, Y.-H., Gusti, A. R., Zhang, Q., Xu, J.-L., \& Zhang, L.-H. (2002). Identification of quorum-sensing $\mathrm{N}$-acyl homoserine lactonases from Bacillus species. Applied and Environmental Microbiology, 68, 1754-1759.

Donlan, R., \& Costerton, J. W. (2002). Biofilms: survival mechanisms of clinically relevant microorganisms. Clinical Microbiology Reviews, 15, 167-193.

Donlan, R. M. (2002). Biofilms: microbial life on surfaces. Emerging Infectious Diseases, 8, 881-890.

Doolittle, M. M., Cooney, J. J., \& Caldwell, D. E. (1995). Lytic infection of Escherichia coli biofilms by bacteriophage T4. Canadian Journal of Microbiology, 41, 12-18.

Dosti, B., Guzel-Seydim, Z., \& Greene, A. K. (2005). Effectiveness of ozone, heat and chlorine for destroying common food spoilage bacteria in synthetic media and biofilms. International Journal of Dairy Technology, 58, 19-24.

Drenkard, E., \& Ausubel, F. M. (2002). Pseudomonas biofilm formation and antibiotic resistance are linked to phenotypic variation. Nature, 416, 740-743.

Dufour, M., Simmonds, R. S., \& Bremer, P. J. (2004). Development of a laboratory scale clean-in-place system to test the effectiveness of "natural" antimicrobials against dairy biofilms. Journal of Food Protection, 67, 1438-1443.

Dunstall, G., Rowe, M. T., Wisdom, G. B., \& Kilpatrick, D. (2005). Effect of quorum sensing agents on the growth kinetics of Pseudomonas spp. of raw milk origin. Journal of Dairy Research, 72, 276-280.

Dykes, G. A., Sampathkumar, B., \& Korber, D. R. (2003). Planktonic or biofilm growth affects survival, hydrophobicity and protein expression patterns of a pathogeni Campylobacter jejuni strain. International Journal of Food Microbiology, 80, 1-10.

Eberhard, A., Burlingame, A. L., Eberhard, C., Kenyon, G. L., Nealson, K. H., \& Oppenheimer, N. J. (1981). Structural identification of autoinducer of Photobacterium fischeri luciferase. Biochemistry, 20, 2444-2449.

European Standard - EN 1276. (1997). Chemical disinfectants and antiseptics quantitative suspension test for the evaluation of bactericidal activity of chemical disinfectants and antiseptics used in food, industrial, domestic, and institutional areas - test method and requirements (phase 2, step 1).

Fatemi, P., \& Frank, J. F. (1999). Inactivation of Listeria monocytogenes/Pseudomonas fluorescens biofilms by peracid sanitizers. Journal of Food Protection, 62, 761-765.

Flint, S. H., Bremer, P. J., \& Brooks, J. D. (1997). Biofilms in dairy manufacturing plant description, current concerns and methods of control. Biofouling, 11, 81-97.

Foley, I., \& Gilbert, P. (1996). Antibiotic resistance of biofilms. Biofouling, 10, 331-346.

Forsythe, S. J., \& Hayes, P. R. (1998). Food hygiene, microbiology and HACCP (3rd ed.). Aspen Publishers.

Frank, J. F., \& Chmielewski, R. (2001). Influence of surface finish on the cleanability of stainless steel. Journal of Food Protection, 64, 1178-1182.

Frank, J. F., Ehlers, J., \& Wicker, L. (2003). Removal of Listeria monocytogenes and poultry soil-containing biofilms using chemical cleaning and sanitizing agents under static conditions. Food Protection Trends, 23, 654-663.

Fuqua, C., \& Greenberg, E. P. (2002). Listening in on bacteria acyl-homoserine lactone signalling. Nature Reviews in Molecular Cell Biology, 3, 685-695.

Fuqua, W. C., Winans, S. C., \& Greenberg, E. P. (1996). Census and consensus in bacterial ecosytems: the LuxR-LuxI family of quorum sensing transcriptional regulators. Annual Reviews in Microbiology, 50, 727-751.

Fux, C. A., Costerton, J. W., Stewart, P. S., \& Stoodley, P. (2005). Survival strategies of infectious biofilms. Trends in Microbiology, 13, 34-40.

Garcia-Almendarez, B. E., Cann, I. K. O., Martin, S. E., Guerrero-Legarreta, I., \& Regalado, C. (2008). Effect of Lactococcus lactis UQ2 and its bacteriocin on Listeria monocytogenes biofilms. Food Control, 19, 670-680.

Gibson, H., Taylor, J. H., Hall, K. E., \& Holah, J. T. (1995). Biofilms and their detection in the food industry. In: Campden and Chorleywood Food Research Association. R\&D Report No. 1.

Gibson, H. J., Taylor, H., Hall, K. E., \& Holah, J. T. (1999). Effectiveness of cleaning techniques used in the food industry in terms of the removal of bacterial biofilms. Journal of Applied Microbiology, 87, 41-48.

Gilbert, P., Allison, D. G., \& McBain, A. J. (2002). Biofilms in vitro and in vivo: do singular mechanisms influx cross-resistance? Journal of Applied Microbiology, 92, 98S-110S.
Gilbert, P., \& McBain, A. J. (2003). Potential impact of increased use of biocides in consumer products on prevalence of antibiotic resistance. Clinical Microbiology Reviews, 16, 189-208.

Gottenbos, B., van der Mei, H. C., Klatter, F., Nieuwenhuis, P., \& Busscher, H. J. (2001). In vitro and in vivo antimicrobial activity of covalently coupled quaternary ammonium silane coatings on silicone rubber. Biomaterials, 23, 1417-1423.

Gram, L. (1993). Inhibitory effect against pathogenic and spoilage bacteria of Pseudomonas strains isolated from spoiled and fresh fish. Applied and Environmental Microbiology, 59, 2197-2203.

Gram, L., Bagge-Ravn, D., Ng, Y. Y., Gymoese, P., \& Vogel, B. F. (2007). Influence of food soiling matrix on cleaning and disinfection efficiency on surface attached Listeria monocytogenes. Food Control, 18, 1165-1171.

Gram, L., Melchiorsen, J., Spanggaard, B., Huber, I., \& Nielsen, T. F. (1999). Inhibition of Vibrio Anguillarum by Pseudomonas fluorescens AH2, a possible probiotic treatment of fish. Applied and Environmental Microbiology, 65, 969-973.

Greene, A. K., Few, B. K., \& Serafini, J. C. (1993). A comparison of ozonation and chlorination for the disinfection of stainless steel surfaces. Journal of Dairy Science, 76, 3617-3620.

Griebe, T., \& Flemming, H.-C. (1998). Biocide-free antifouling strategy to protect RO biofouling. Desalination, 118, 153-156.

Hall-Stoodley, L., \& Stoodley, P. (2002). Developmental regulation of microbial biofilms. Current Opinion in Biotechnology, 13, 228-233.

van Hamme, J. D., Singh, A., \& Ward, O. P. (2006). Physiological aspects Part 1 in a series of papers devoted to surfactants in microbiology and biotechnology. Biotechnology Advances, 24, 604-620.

Hanlon, G. W., Denyer, S. P., Ollif, C. J., \& Ibrahim, L. J. (2001). Reduction in exopolysaccharide viscosity as an aid to bacteriophage penetration through Pseudomonas aeruginosa biofilms. Applied and Environmental Microbiology, 67, 2746-2753.

Harbron, R. S., \& Kent, C. A. (1988). Aspects of cell adhesion. In L. F. Melo, T. R. Bott, \& C. A. Bernardo (Eds.), NATO ASI series, Vol. 145 (pp. 125-140).

Hashimoto, H. (2001). Evaluation of the anti-biofilm effect of a new antibacterial silver citrate/lecithin coating in an in-vitro experimental system using a modified Robbins device. Journal of the Japanese Association for Infectious Diseases, 75, 678-685.

Heinzel, M. (1998). Phenomena of biocide resistance in microorganisms. International Biodeterioration E Biodegradation, 41, 225-234.

Hibma, A. M., Jassim, S. A., \& Griffiths, M. W. (1997). Infection and removal of L-forms of Listeria monocytogenes with bred bacteriophage. International Journal of Food Microbiology, 34, 197-207.

Holah, J. T. (1992). Industrial monitoring: hygiene in food processing. In L. F. Melo, T. R. Bott, M. Fletcher, \& B. Capdeville (Eds.), Biofilms - Science and technology (pp. 645-659)

Hughes, K. A., Sutherland, I. W., Clark, J., \& Jones, M. V. (1998). Bacteriophage and associated polysaccharide depolymerises - novel tools for study of bacterial biofilms. Journal of Applied Microbiology, 85, 583-590.

Hughes, K. A., Sutherland, I. W., \& Jones, M. V. (1998). Biofilm susceptibility to bacteriophage attack: the role of phage-borne polysaccharide depolymerase. Microbiology, 144, 3039-3047.

Jacquelin, L. F., Le Magrex, E., Brisset, L., Carquin, J., Berthet, A., \& Choisy, C. (1994). Synergy effect of enzymes or surfactants in association with a phenolic disinfectant on a bacterial biofilm. Patholologie Biologie, 42, 425-431.

Jahn, A., \& Nielsen, P. H. (1998). Cell biomass and exopolymer composition in sewer biofilms. Water Science and Technology, 37, 17-24.

Janneke, G., Wijman, E., Patrick, P., de Leeuw, L. A., Mooezelaar, R., Zwietering, M. H., et al. (2007). Air-liquid interface biofilms of Bacillus cereus: formation, sporulation, and dispersion. Applied and Environmental Microbiology, 73, 1481-1488.

Jessen, B., \& Lammert, L. (2003). Biofilm and disinfection in meat processing plants. International Biodeterioration \& Biodegradation, 51, 265-269.

Johansen, C., Falholt, P., \& Gram, L. (1997). Enzymatic removal and disinfection of bacterial biofilms. Applied and Environmental Microbiology, 9, 3724-3728.

Kives, J., Guadarrama, D., Orgaz, B., Rivera-Sem, A., Vazquez, J., \& SanJose, C. (2005). Interactions in biofilms of Lactococcus lactis ssp. cremoris and Pseudomonas fluorescens cultured in cold UHT milk. Journal of Dairy Science, 88, 4165-4171.

Klueh, U., Wagner, V., Kelly, S., Johnson, A., \& Bryers, J. D. (2000). Efficacy of silvercoated fabric to prevent bacterial colonization and subsequent device-based biofilm formation. Journal of Biomedical Materials Research 621-631.

Kreske, A. C., Ryu, J.-H., Pettigrew, C. A., \& Beuchat, L. R. (2006). Lethality of chlorine, chlorine dioxide, and a commercial produce sanitizer to Bacillus cereus and Pseudomonas in a liquid detergent, on stainless steel, and in biofilm. Journal of Food Protection, 14, 2621-2634.

Kuda, T., Yano, T., \& Kuda, M. T. (2008). Resistances to benzalkonium chloride of bacteria dried with food elements on stainless steel surface. LWT - Food Science and Technology, 41, 988-993.

Kudva, I. T., Jelacic, S., Tarr, P. I., Youderian, P., \& Hovde, C. J. (1999). Biocontrol of Escherichia coli 0157 with 0157-specific bacteriophages. Applied and Environmental Microbiology, 65, 3767-3773.

Kumar, C. G., \& Anand, S. K. (1998). Significance of microbial biofilms in food industry: review. International Journal of Food Microbiology, 42, 9-27.

Langsrud, S., Sidhu, M. A., Heir, E., \& Holck, A. L. (2003). Bacterial disinfectant resistance - a challenge for the food industry. International Biodeterioration $\mathcal{E}$ Biodegradation, 51, 283-290.

Lapidot, A., Romling, U., \& Yaron, S. (2006). Biofilm formation and the survival of Salmonella typhimurium on parsley. International Journal of Food Microbiology, 109, 229-233. 
Lehner, A., Riedel, K., Eberl, L., Breeuwer, P., Diep, B., \& Stephan, R. (2005). Biofilm formation, extracellular polysaccharide production, and cell-to-cell signalling in various Enterobacter sakazakii strains: aspects promoting environmental persistence. Journal of Food Protection, 68, 2287-2294.

Leriche, V., \& Carpentier, B. (2000). Limitation of adhesion and growth of Listeria monocytogenes on stainless steel surfaces by Staphylococcus sciuri biofilms. Journal of Applied Microbiology, 88, 594-605.

Lindsay, D., Brözel, V. S., Mostert, J. F., \& Von Holy, A. (2002). Differential efficacy of a chlorine dioxide-containing sanitizer against single and binary biofilms of a dairy associated Bacillus cereus and a Pseudomonas fluorescens isolate. Journal of Applied Microbiology, 92, 352-361.

Lindsay, D., Brözel, V. S., \& von Holy, A. (2006). Biofilm-spore response in Bacillus cereus and Bacillus subtilis during nutrient limitation. Journal of Food Protection, $69,1168-1172$

Lomander, A., Schreuders, P., Russek-Cohen, E., \& Ali, L. (2004). Evaluation of chlorines impact on biofilms on scratched stainless steel surfaces. Bioresources Technology, 94, 275-283.

Lu, T. K., \& Collins, J. J. (2007). Dispersing biofilms with engineered enzymatic bacteriophage. Proceedings of the National Academy of Sciences USA, 104, 1119711202.

Machuca, A., \& Milagres, A. M. F. (2003). Use of CAS-agar plate modified to study the effect of different variables on the siderophore production by Aspergillus. Letters in Applied Microbiology, 36, 177-181.

Mah, T.-F., \& O'Toole, G. A. (2001). Mechanisms of biofilm resistance to antimicrobial agents. Trends in Microbiology, 9, 34-39.

Mahdavi, M., Jalali, M., \& Kermanshahi, R. K. (2007). The effect of nisin on biofilm forming foodborne bacteria using microtiter plate method. Research in Pharmaceutical Sciences, 2, 113-118.

Marques, S. C., Rezende, J. G. O. S., Alves, L. A. F., Silva, B. C., Alves, E., Abreu, L. R., et al. (2007). Formation of biofilms by Staphylococcus aureus on stainless steel and glass surfaces and its resistance to some selected chemical sanitizers. Brazilian Journal of Microbiology, 38, 538-543.

Maukonen, J., Mättö, J., Wirtanen, G., Raaska, L., Mattila-Sandholm, T., \& Saarela, M. (2003). Methodologies for the characterization of microbes in industrial environments: a review. Journal of Industrial Microbiology and Biotechnology, 30, 327-356.

McBain, A. J., Rickard, A. H., \& Gilbert, P. (2002). Possible implications of biocide accumulation in the environment on the prevalence of bacterial antibiotic resistance. Journal of Industrial Microbiology and Biotechnology, 29, $326-330$.

Meyer, B. (2003). Approaches to prevention, removal and killing of biofilms. International Biodeterioration \& Biodegradation, 51, 249-253.

Meylheuc, T., Renault, M., \& Bellon-Fontaine, M. N. (2006). Adsorption of a biosurfactant on surfaces to enhance the disinfection of surfaces contaminated with Listeria monocytogenes. International Journal of Food Microbiology, 109, 71-78.

Midelet, G., \& Carpentier, B. (2004). Impact of cleaning and disinfection agents on biofilm structure and on microbial transfer to a solid model food. Journal of Applied Microbiology, 97, 262-270.

Millsap, K. W., Reid, G., van der Mei, H. C., \& Busscher, H. J. (1997). Adhesion of Lactobacillus species in urine and phosphate buffer to silicone rubber and glass under flow. Biomaterials, 18, 87-91.

Mireles, J. R., Toguchi, A., \& Harshey, R. M. (2001). Salmonella enterica serovar Typhimurium swarming mutants with altered biofilm-forming abilities: surfactin inhibits biofilm formation. Journal of Bacteriology, 183, 5848-5854.

Mittelman, M. W. (1998). Structure and functional characteristics of bacterial biofilms in fluid processing operations. Journal of Dairy Science, 81, 2760-2764.

Morton, L. H. G., Greenway, D. L. A., Gaylarde, C. C., \& Surman, S. B. (1998), Consideration of some implications of the resistance of biofilms to biocides. International Biodeterioration and Biodegradation, 41, 247-259.

Møretrø, T., \& Langsrud, S. (2004). Listeria monocytogenes: biofilm formation and persistence in food processing environments. Biofilms, 1, 107-121.

Mosteller, T. M., \& Bishop, J. R. (1993). Sanitizer efficacy against attached bacteria in milk biofilm. Journal of Food Protection, 56, 34-41.

Musk, D. J., Banko, D. A., \& Hergenrother, P. J. (2005). Iron salts perturb biofilm formation and disrupt existing biofilms of Pseudomonas aeruginosa. Chemistry $\mathcal{E}$ Biology, 12, 786-796.

Neu, T. R. (1996). Significance of bacterial surface-active compounds in interaction of bacteria with interfaces. Microbiological Reviews, 60, 151-166.

Nitschke, M., \& Costa, S. G. V. A. O. (2007). Biosurfactants in food industry. Trends in Food Science and Technology, 18, 252-259.

Ntsama-Essomba, C., Boutier, S., Ramaldes, M., Dubois-Brissonet, F., \& Fourniat, J. (1997). Resistance of Escherichia coli growing as biofilms to disinfectants. Veterinary Research, 28, 353-363.

Oliver, S. P., Jayarao, B. M., \& Almeida, R. A. (2005). Food borne pathogens in milk and the dairy farm environment: food safety and public health implications. Foodborne Pathogens and Disease, 2, 115-129.

O'Toole, G., Kaplan, H. B., \& Kolter, R. (2000). Biofilm formation as microbial development. Annual Reviews in Microbiology, 54, 49-79.

Oulahal, N., Brice, W., Martial, A., \& Degraeve, P. (2008). Quantitative analysis of survival Staphylococcus aureus or Listeria innocua on two types of surfaces: propylene and stainless steel in contact with three different dairy products. Food Control, 19, 178-185.

Oulahal-Lagsir, N., Martial-Gros, A., Bonneau, M., \& Blum, L. J. (2003). “Escherichia coli-milk" biofilm removal from stainless steel surfaces: synergism between ultrasonic waves and enzymes. Biofouling, 19, 159-168.
Pan, Y., Breidt, F., Jr., \& Kathariou, S. (2006). Resistance of Listeria monocytogenes biofilms to sanitizing agents in a simulated food processing environment. Applied and Environmental Microbiology, 72, 7711-7717.

Park, A.-I., Daeschel, M. A., \& Zhao, Y. (2004). Functional properties of antimicrobial lysozyme-chitosan composite films. Journal of Food Safety, 69, 215-221.

Parkar, S. G., Flint, S. H., \& Brooks, J. D. (2004). Evaluation of the effect of cleaning regimes on biofilms of thermophilic bacilli on stainless steel. Journal of Applied Microbiology, 96, 110-116.

Parsek, M. R., \& Greenberg, E. P. (2005). Sociomicrobiology: the connections between quorum sensing and biofilms. Trends in Microbiology, 13, 27-33.

Passador, L., Cook, J. M., Gambello, M. J., Rust, L., \& Iglewski, B. H. (1993). Expression of Pseudomonas aeruginosa virulence genes requires cell-to-cell communication. Science, 260, 1127-1130.

Patel, J. D., Ebert, M., Ward, R., \& Anderson, J. M. (2007). S. epidermidis biofilm formation: effects of biomaterial surface chemistry and serum proteins. Journa of Biomedical Materials Research A, 80, 742-751.

Pearson, J. P., Delden, C. V., \& Iglewski, B. H. (1999). Active efflux and diffusion are nvolved in transport of Pseudomonas aeruginosa cell-to-cell signals. Journal of Bacteriology, 181, 1203-1210.

Pearson, J. P., Passador, L., Iglewski, B. H., \& Greenberg, E. P. (1995). A second $\mathrm{N}$-acylhomoserine lactone signal produced by Pseudomonas aeruginosa. Proceedings of the National Academy of Science USA, 92, 1490-1494.

Pereira, A., Mendes, J., \& Melo, L. F. (2008). Using nanovibrations to monitor biofouling. Biotechnology and Bioengineering, 15, 1407-1415.

Pereira, A., Mendes, J., \& Melo, L. F. (2009). Monitoring cleaning-in-place of shampoo films using nanovibration technology. Sensors and Actuators B: Chemical, 136, 376-382.

Pereira, M. O., Machado, S., Simões, L. C., Machado, I., Simões, M., \& Vieira, M. J. (2006). Influence of material type and surface benzalkonium chloride preconditioning on biofilm formation and activity. In D. I. Wilson, J. Y. M. Chew, P. J. Freyer, \& A. P. M. Hasting (Eds.), Proceedings of the international conference fouling, cleaning and disinfection in food processing (pp. 347-353), Cambridge, UK.

Philip-Chandy, R., Scully, P. J., Eldridge, P., Kadim, H. J., Grapin, G., Jonca, M. G., et al. 2000). An optical fiber sensor for biofilm measurement using intensity modulation and image analysis. IEEE Journal of Quantum Electronics, 6, 764-772.

Rasmussen, T. B., Skindersoe, M. E., Bjarnsholt, T., Phipps, R. K., Christensen, K. B. Jensen, P. O., et al. (2005). Identity and effects of quorum-sensing inhibitors produced by Penicillium species. Microbiology, 151, 1325-1340.

Rivardo, F., Turner, R. J., Allegrone, G., Ceri, H., \& Martinotti, M. G. (2009). Antiadhesion activity of two biosurfactants produced by Bacillus spp. prevents biofilm formation of human bacterial pathogens. Applied Microbiology and Biotechnology, $83,541-553$.

Robbins, J. B., Fisher, C. W., Moltz, A. G., \& Martin, S. E. (2005). Elimination of Listeria monocytogenes biofilms with ozone, chlorine, and hydrogen peroxide. Journal of Food Protection, 68, 494-498.

Rodrigues, L. R., van der Mei, H. C., Teixeira, J. A., \& Oliveira, R. (2004). Biosurfactant from Lactococcus lactis 53 inhibits microbial adhesion on silicone rubber. Applied Microbiology and Biotechnology, 66, 306-311.

Rogers, J., Dowsett, A. B., Dennis, P. J., Lee, J. V., \& Keevil, C. W. (1994). Influence of plumbing materials on biofilm formation and growth of Legionella pneumophila in potable water systems. Applied and Environmental Microbiology, 60 $1842-1851$

Rosmaninho, R., Santos, O., Nylander, T., Paulsson, M., Müller-Steinhagen, H., \& Melo, L. (2007). Modified stainless steel surfaces targeted to reduce fouling evaluation of fouling by milk components. Journal of Food Engineering, 80, 1176-1187.

Rossmore, H. W. (1995). Introduction to biocide use. In H. W. Rossmoore (Ed.) Handbook of biocide and preservative use (pp. 1-18)

Røssland, E., Langsrud, T., Granum, P. E., \& Sørhaug, T. (2005). Production of antimicrobial metabolites by strains of Lactobacillus or Lactococcus co-cultured with Bacillus cereus in milk. International Journal of Food Microbiology, 98, 193-200.

Ryan, R. P., \& Dow, J. M. (2008). Diffusive signals and interspecies communication in bacteria. Microbiology, 154, 1845-1858.

Salo, S., Ehavald, H., Raaska, L., Vokk, R., \& Wirtanen, G. (2006). Microbial surveys in Estonian dairies. LWT - Food Science and Technology, 39, 460-471.

Sauer, K., \& Camper, A. K. (2001). Characterization of phenotypic changes in Pseudomonas putida in response to surface-associated growth. Journal of Bacteriology, 183, 6579-6589.

Schlech, W. F., Lavigne, P. M. Bortolussi, R. A, Allen, A. C, Haldane, E. V., Wort, A. I et al. (1983). Epidemic listeriosis - evidence for transmission by food. New England Journal of Medicine, 308, 203-206.

Sharma, M., \& Anand, S. K. (2002a). Characterization of constitutive microflora of biofilms in dairy processing lines. Food Microbiology, 19, 627-636.

Sharma, M., \& Anand, S. K. (2002b). Biofilms evaluation as an essential componen of HACCP for food/dairy industry - a case. Food Control, 13, 469-477.

Sharma, M., Ryu, J. H., \& Beuchat, L. R. (2005). Inactivation of Escherichia coli 0157:H7 in biofilm on stainless steel by treatment with an alkaline cleaner and a bacteriophage. Journal of Applied Microbiology, 99, 449-459.

Sidhu, M. S., Langsrud, S., \& Holck, A. (2001). Disinfectant and antibiotic resistance of lactic acid bacteria isolated from food industry. Microbial Drug Resistance, 7, 73-83.

Sihorkar, V., \& Vyas, S. P. (2001). Biofilm consortia on biomedical and biological surfaces: delivery and targeting strategies. Pharmaceutical Research, 18, 1254-1427.

Sillankorva, S., Oliveira, D. R., Vieira, M. J., Sutherland, I. W., \& Azeredo, J. (2004) Bacteriophage $\Phi \mathrm{S} 1$ infection of Pseudomonas fluorescens planktonic cells versus biofilms. Biofouling, 20, 133-138. 
Simões, L. C., Simões, M., \& Vieira, M. J. (2007). Biofilm interactions between distinct bacterial genera isolated from drinking water. Applied and Environmental Microbiology, 73, 6192-6200.

Simões, M., Bennett, R. N., \& Rosa, E. A. S. (2009). Understanding antimicrobial activities of phytochemicals against multidrug resistant bacteria and biofilms. Natural Product Reports, 26, 746-757.

Simões, M., Pereira, M. O., \& Vieira, M. J. (2005). Effect of mechanical stress on biofilms challenged by different chemicals. Water Research, 39, 5142-5152.

Simões, M., Sillankorva, S., Pereira, M. O., Azeredo, J., \& Vieira, M. J. (2007). The effect of hydrodynamic conditions on the phenotype of Pseudomonas fluorescens biofilms. Biofouling, 24, 249-258.

Simões, M., Simões, L. C., Cleto, S., Pereira, M. O., \& Vieira, M. J. (2008). The effects of a biocide and a surfactant on the detachment of Pseudomonas fluorescens from glass surfaces. International Journal of Food Microbiology, 121, 335-341.

Simões, M., Simões, L. C., Machado, I., Pereira, M. O., \& Vieira, M. J. (2006). Control of flow-generated biofilms using surfactants - evidence of resistance and recovery. Food and Bioproducts Processing, 84, 338-345.

Simões, M., \& Vieira, M. J. (2009). Persister cells in Pseudomonas fluorescens biofilms treated with a biocide. In Proceedings of the international conference processes in biofilms: Fundamentals to applications (pp. 58-62), Davis, CA, USA

Singh, P. K., Parsek, M. R., Greenberg, P. E., \& Welsh, M. J. (2002). A component of innate immunity prevents bacterial biofilm development. Nature, 417, 552-555.

Smith, L., Fratamico, P. M., \& Novak, J. S. (2004). Quorum sensing: a primer for food microbiologists. Journal of Food Protection, 67, 1053-1070.

Somers, E. B., Schoeni, J. L., \& Wong, A. C. L. (1994). Effect of trisodium phosphate on biofilm and planktonic cells of Campylobacter jejuni, Escherichia coli 0157: H7, Listeria monocytogenes and Salmonella Typhimurium. International Journal of Food Microbiology, 22, 269-276.

Somers, E. B., \& Wong, A. C. (2004). Efficacy of two cleaning and sanitizing combinations on Listeria monocytogenes biofilms formed at low temperature on a variety of materials in the presence of ready-to-eat-meat residue. Journal of Food Protection, 67, 2218-2229.

Splendiani, A., Livingston, A. G., \& Nicolella, C. (2006). Control membrane-attached biofilms using surfactants. Biotechnology and Bioengineering, 94, 15-23.

Srinivasan, R., Stewart, P. S., Griebe, T., Chen, C.-I., \& Xu, X. (1995). Biofilm parameters influencing biocide efficacy. Biotechnology and Bioengineering, 46, 553560.

Stoodley, P., Lewandowski, Z., Boyle, J. D., \& Lappin-Scott, H. M. (1999). Influence of hydrodynamic conditions and nutrients on biofilm structure. Journal of Applied Microbiology, 85, 19S-28S.

Surette, M. G., Miller, M. B., \& Bassler, B. L. (1999). Quorum sensing in Escherichia coli, Salmonella typhimurium, and Vibrio harveyi: a new family of genes responsible for autoinducer production. Proceedings of the National Academy of Sciences USA, 96, 1639-1644.

Sutherland, I. W. (2001). The biofilm matrix - an immobilized but dynamic microbial environment. Trends in Microbiology, 9, 222-227.

Sutherland, I. W., Hughes, K. A., Skillman, L. C., \& Tait, K. (2004). The interaction of phage and biofilms. FEMS Microbiology Letters, 232, 1-6.

Tait, K., \& Sutherland, I. W. (1998). Antagonistic interactions amongst bacteriocinproducing enteric bacteria in dual species biofilms. Journal of Applied Microbiology, 93, 345-352.

Thouvenin, M., Langlois, V., Briandet, R., Langlois, J. Y., Guerin, P. H., Peron, J. J., et al (2003). Study of erodable paint properties involved in antifouling activity. Biofouling, 19, 177-186.

Tsibouklis, J., Stone, M., Thorpe, A. A., Graham, P., Nevell, T. G., \& Ewen, R. J. (2000). Inhibiting bacterial adhesion onto surfaces: the non-stick coating approach. International Journal of Adhesion, 20, 91-96.
Tsuneda, S., Aikawa, H., Hayashi, H., Yuasa, A., \& Hirata, A. (2003). Extracellular polymeric substances responsible for bacterial adhesion onto solid surface. FEMS Microbiology Letters, 223, 287-292.

Unnerstad, H., Bannerman, E., Bille, J., Danielsson-Tham, M.-L., Waak, E., \& Tham, W. (1996). Prolonged contamination of a dairy with Listeria monocytogenes. Netherland Milk Dairy Journal, 50, 493-499.

Valenti, P., \& Antonini, G. (2005). Lactoferrin: an important host defence against microbial and viral attack. Cell and Molecular Life Sciences, 62, 2576-2587.

Valle, J., Re, D. S., Henry, N., Fontaine, T., Balestrino, D., Latour-Lambert, P., et al (2006). Broad-spectrum biofilm inhibition by a secreted bacterial polysaccharide. Proceedings of the National Academy of Sciences USA, 103, $12558-12563$.

Veran, J. (2002). Biofouling in food processing: biofilm or biotransfer potential? Food and Bioproducts Processing, 80, 292-298.

Verstraeten, N., Braeken, K., Debkumari, B., Fauvart, M., Fransaer, J., Vermant, J., et al. (2008). Living on a surface: swarming and biofilm formation. Trends in Microbiology, 16, 496-506.

Vieira, M. J., Melo, L., \& Pinheiro, M. M. (1993). Biofilm formation: hydrodynamic effects on internal diffusion and structure. Biofouling, 7, 67-80.

Vilar, M. J., Yus, E., Sanjuan, M. L., Dieguez, F. J., \& Rodriguez-Otero, J. L. (2007). Prevalence of and risk factors for Listeria species on dairy farms. Journal of Dairy Science, 90, 5083-5088.

Waak, E., Tham, W., \& Danielsson-Tham, M.-L. (2002). Prevalence and fingerprinting of Listeria monocytogenes strains isolated from raw whole milk in farm tanks and in dairy plant receiving tanks. Applied and Environmental Microbiology, 68, 3366-3370.

Walencka, E., Różalska, S., Sadowska, B., \& Różalska, B. (2008). The influence of Lactobacillus acidophilus-derived surfactants on staphylococcal adhesion and biofilm formation. Folia Microbiologica, 53, 61-66.

Weng, Y.-M., Chen, M.-J., \& Chen, W. (1999). Antimicrobial food packing materials from poly(ethylene-co-methacrylic acid). LWT - Food Science and Technology, 32, 191-195.

Whitchurch, C. B., Tolker-Nielsen, T., Ragas, P. C., \& Mattick, J. S. (2002). Extracellular DNA required for bacterial biofilm formation. Science, 295, 1487.

Whitehead, K. A., Collingon, J. S., \& Verran, J. (2004). The production of surfaces of defined topography and chemistry for microbial retention studies, using ion beam sputtering technology. International Biodeterioration E' Biodegradation, 54, 143-151.

Whitehead, K. A., Collingon, J., \& Verran, J. (2005). Retention of microbial cells in substratum surface features of micrometer and sub-micrometer dimensions. Colloids and Surfaces B: Biointerfaces, 41, 129-138.

Wiedmann, M., Weilmeier, D., Dineen, S. S., Ralyea, R., \& Boor, K. J. (2000). Molecular and phenotypic characterization of Pseudomonas sp. isolated from milk. Applied and Environmental Microbiology, 66, 2085-2095.

Wingender, J., Neu, T. R., \& Flemming, H.-C. (1999). What are bacterial extracellular polymeric substances? In J. Wingender, T. R. Neu, \& H.-C. Flemming (Eds.), Microbial extracellular polymeric substances - Characterization, structure and function (pp. 1-19).

Wirtanen, G., Saarela, M., \& Mattila-Sandholm, T. (2000). Biofilms - impact on hygiene in food industries. In J. D. Bryers (Ed.), Biofilms II: Process analysis and applications (pp. 327-372).

Wong, A. C. L. (1998). Biofilm in food processing environments. Journal of Dairy Science, 81, 2765-2770.

Zhao, T., Doyle, M. P., \& Zhao, P. (2004). Control of Listeria monocytogenes in a biofilm by competitive-exclusion microorganisms. Applied and Environmental Microbiology, 70, 3996-4003.

Zobell, C. E. (1943). The effect of solid surfaces upon bacterial activity. Journal of Bacteriology, 46, 39-56. 